\title{
TRUST AND FOR-PROFIT PHILANTHROPY
}

\section{From Surrey's private foundation to Zuckerberg's limited liability company}

\author{
Steven Dean and Dana Brakman Reiser
}

Philanthropy has left an indelible mark on the United States over the last half century. To offer just one example, a foundation proved instrumental in the creation of the nation's emergency 911 response system in the 1970s (Kohler, 2007, p. 1). Unfortunately, the foundation rests on an increasingly fragile foundation. Wealthy donors have begun to avoid the very structures created to support philanthropy, forgoing the generous tax benefits they provide. In 2015, Mark Zuckerberg and Priscilla Chan proudly announced the creation of the Chan Zuckerberg Initiative - a limited liability company - to give away $99 \%$ of their net worth.

This chapter offers an unconventional explanation for the diminished allure of foundations and the rise of for-profit philanthropy embodied in alternative philanthropic vehicles such as the limited liability company. In our previous work, we have shown how trust plays a critical role in hindering the rise of social enterprise (Brakman Reiser and Dean, 2017, pp. 11-13). Designed to pursue profits and social goals simultaneously, an absence of trust between investors and social entrepreneurs chokes off access to capital these ventures need to grow.

Rousseau famously observed that hunters unable to trust one another will never share the big prize - the stag - and will instead be condemned to hunt hares on their own. Both untrusting and untrusted, social enterprises have been unable to raise capital from investors. Trust remains out of reach because each lacks the means to make a reliable commitment to the other.

In 1969, a legislative compromise we call the Grand Bargain solved a similar trust gap between philanthropists and the public. Gilded Age industrialists like Rockefeller and Carnegie pioneered the concept of a philanthropic foundation, designed to manage and distribute funds for charitable purposes. Newly minted moguls followed suit in the ensuing decades. By mid-century, concern was running high about abuses within these organizations. A series of inquiries by administrative agencies and congressional committees led to major reform legislation in 1969.

The Tax Reform Act of 1969 can be viewed as "a necessary part of the bargain to encourage charitable activities . . reflect[ing] a series of trade-offs that occurred in the U.S. legislative and administrative process that result in a robust charitable sector" (Zolt, 2021, p. 26). Now officially dubbed "private foundations" by statute, they retained the capacity for perpetual life and significant tax benefits in exchange for government regulation and transparency. 
The Grand Bargain channeled foundation resources toward public-regarding activities and at least some significant current spending and away from entanglements with business interests and politics. It demanded heightened accountability through new prophylactic rules against non-charitable distributions and transactions between foundations and their donors and managers. The enhanced disclosure scheme it imposed allowed for tracking and enforcement of this strengthened regulatory framework. By imposing these affirmative obligations on foundations, the Grand Bargain directly targeted two of the main criticisms of modern-day philanthropy and its "tax incentives for giving ... that they may be regressive and undemocratic" (OECD, 2020, p. 2).

Today, alternatives to the private foundation, notably philanthropy LLCs, commercially affiliated donor-advised funds and strategic corporate philanthropy defy the Grand Bargain. These for-profit philanthropy tools allow elites to evade the regulatory architecture the Grand Bargain erected. Just as social enterprise blurs the boundaries between doing business and doing social good, for-profit philanthropy phenomena upend the Grand Bargain's balance between elite power and public control. The possible dissolution of that bargain and the cautionary tale of social enterprise suggest how easily trust can slip through our fingers.

We trace the Grand Bargain's decline to developments in tax policy designed to enhance transparency that, in no small irony, can in turn be traced to the Grand Bargain itself. The tax expenditure budget that grew out of the Tax Reform Act of 1969 may have doomed the Grand Bargain simply by clearly and publicly tallying its costs. That lost innocence transformed philanthropy from a shared act of faith into a transaction, with the Chan Zuckerberg Initiative as its logical conclusion.

\section{Trust to transaction}

The link between taxation and philanthropy has been indisputable since Carnegie wrote his famous essay "Wealth." Not one to mince words, Carnegie concluded that by "taxing estates heavily at death the state marks its condemnation of the selfish millionaire's unworthy life" (1889, p. 659). In practice, carrying out the threat implicit in such progressive taxes has proven difficult. Even when rates are high, loopholes and lax enforcement shield wealthy taxpayers from the harsh judgment Carnegie envisioned.

Philanthropic reforms Congress embraced in 1969 targeted perceived abuses by curbing tax benefits and enacting exacting penalties on political activity and a range of transactions deemed suspect. As Carnegie predicted, philanthropists seized on that sternly worded invitation to transform "the surplus wealth of the few" into "in the best sense, the property of the many, because administered for the common good" (Carnegie, 1889, p. 660). Since 1969, the Gates Foundation and countless others have had an enormous impact in areas ranging from health to education.

The Tax Reform Act of 1969 would - by fueling the subsequent work of one of its chief architects, Stanley Surrey - plant the seeds of the Grand Bargain's undoing. As Surrey put it, he "came to recognize that most of the matters considered in 1969 - whether they were adopted or rejected in the final legislation - related to items in the Tax Expenditure Budget" (Surrey, 1973, p. viii). The Grand Bargain succeeded for any number of reasons, but perhaps the most important was that both wealthy elites and the public could believe they got the better of it. The tax expenditure budget, by design, made that impossible. Stripping all mystery from the exchange of tax breaks for philanthropic largesse may have doomed the Grand Bargain. 


\section{A The picaresque story of the income tax}

The world has changed in the half-century since the Grand Bargain created a fruitful and unlikely partnership between the public and wealthy philanthropists. The most striking changes, the rise of new technologies and old inequalities, may not pose the greatest threat to the Grand Bargain and its philanthropic stag hunt. This chapter highlights deeper challenges fueled by legal changes so gradual they often go unnoticed. From election law to the income and estate taxes, a slowly remade landscape has left the Grand Bargain intact while stripping it of the power to generate trust.

In this chapter, we tell the picaresque story of the income tax to show how legal change has made trust between philanthropists and the public harder to come by. Enshrined in the U.S. Constitution a century ago to "put the burdens of government justly upon the backs of the people," the income tax began modestly, paid by an elite few (Jennings Bryan, 1896). In the decades that followed the ratification of the 16th Amendment, the income tax evolved into a shared ritual at the heart of our civic life. Today, more Americans file federal tax returns than vote.

By 1969 - when the Grand Bargain was struck - top marginal income tax rates above $70 \%$ had become an enduring presence for high-income taxpayers. Those rates tell a compelling story of the power of taxation to constrain elite influence. Recent calls to raise top marginal rates to match those prevailing at the time of the Grand Bargain underscore the continuing appeal of that narrative. The Grand Bargain reveals a more complex reality, highlighting both unexpected limits and surprising power.

The specter of high tax rates played the role Carnegie once envisioned, but not because the rich felt bound to pay them. The Grand Bargain allowed the wealthy to avoid high marginal rates. Although they had already mastered that feat, the 1969 Tax Reform Act allowed them to do so respectably. In the 1950s and 60s, support for high wartime tax burdens might have waned, but the rates themselves had not. That confluence of high rates and skepticism made tax avoidance widespread (Bank, 2017, p. 128).

Nominal rates were high, but well-advised taxpayers could blunt their impact. Aggressive tax planning fueled a very different reality in which charitable contributions could, as described in the following, quite literally pay. Today, by any measure, the burden of the income tax falls lightly on elite shoulders. Reduced marginal income tax rates tell only part of the story. Technical changes - applying capital gains treatment to most dividends, for example - mean that corporate earnings distributed to shareholders once taxed at rates above $90 \%$ now face a maximum rate of $20 \%$.

Other changes matter as much or more to the fate of the Grand Bargain but can be seen neither in the rise and fall of rates nor the fate of loopholes. A half century ago, tax planning could tame the threat of high rates, but not without risk. Today, wealthy individuals have little to fear. A report by the Treasury's Inspector General for Tax Administration issued in 2020 revealed that "high-income nonfilers owing billions of dollars" were simply being ignored by an underfunded Internal Revenue Service. Together, lower rates, larger loopholes and weakened enforcement reveal an altered landscape that makes the Grand Bargain's benefits far less appealing than 50 years ago.

\section{B Regulating philanthropy}

Simply doubling top marginal tax rates would be both too much and not enough to reinvigorate the Grand Bargain. As early as 1957, Surrey highlighted how "high rates of the individual 
income tax, and of the estate and gift taxes" powered tax preferences like the foundation (Surrey, 1957, p. 1149). Yet as Surrey understood all too well, translating high rates into revenues can be surprisingly difficult.

Carnegie and Surrey both understood how tax law could play a central role in the rise and fall of the Grand Bargain, but tax does not tell the whole story. While the value of tax benefits shrank, the opportunity costs of embracing the Grand Bargain's constraints on political activity, in-kind contributions and privacy ballooned. The Grand Bargain brought federal oversight to almost every component of foundation operations in service of restraining the real and potential excesses of these powerful institutions and the people behind them. It tells foundations how to spend the money they distribute; how to invest the money they retain; and how to manage their relationships with fiduciaries, employees and donors.

Federal tax law regulates foundation spending on virtually all possible dimensions. A payout requirement addresses both the timing and the amount of foundation spending by penalizing foundations that fail to distribute at least $5 \%$ of their assets each year for charitable purposes. Through excise taxes imposed on certain types of expenditures, it also limits the potential recipients of foundations' resources and the purposes for which they may be distributed. Faced with these constraints, philanthropists such as Zuckerberg and Chan have rejected the private foundation in favor of a limited liability company. Although it may seem otherwise, that offers reason for optimism.

Nowhere can the magnitude of the growing sacrifice choosing a private foundation represents be seen more starkly than in the changing role of money in politics. In an election law environment that imposes ever fewer limitations on political spending by elites, pledging political abstinence by forming a private foundation has become costly. So philanthropists find ways to avoid them.

Allowing foundations to engage in political activity - replacing outright prohibitions with limits and minimum standards of accountability - could replicate the Grand Bargain's success, nudging elites towards benign forms of political engagement. It could help to turn the clock back to 1969, preserving the philanthropic partnership between the public and elites against the entropic pull of profit. The Grand Bargain harnessed tax avoidance. The same might be accomplished with political spending.

This chapter explores three distinct ways to breathe new life into the Grand Bargain. A return to steeply progressive post-war rates - and all that goes with them - represents only one path back towards a reinvigorated Grand Bargain. As detailed in the following, that route may be the least promising. Reducing the opportunity costs of embracing regulated philanthropic forms by remaking the relationship between politics and philanthropy could have an even greater impact. Finally, a wealth tax could deliver accountability in timing, transparency and targeting for the age of for-profit philanthropy.

\section{The evolving income tax}

In 2019, Congresswoman Ocasio-Cortez alluded to a 70\% marginal tax rate on income, and many found the idea astonishing. A century of history shows that we might be equally surprised by the rates in effect today. ${ }^{1}$ A careful study of the income tax reveals many more twists and turns than the steadily falling tax rates of the last three decades suggest. In countless ways, today's income tax bears little resemblance to the one embraced after the ratification of the 16th Amendment.

At first, the vast majority of Americans paid no income tax at all. In terms of its reach, the first modern U.S. income tax can be roughly compared to today's estate tax, targeting only the 
most affluent. And the tax was only imposed on amounts far in excess of anything a typical worker could hope to earn (or, in the case of the estate tax, to accumulate). After the Second World War, that would change as the role of the income tax in American life grew.

Initially a tool designed blunt the excesses of inequality by compelling the wealthiest to contribute more, a vast expansion would make the income tax part of most American lives. Once a tax on elites, the income tax became a tax on the masses. In the years since, a further expansion - notably in the form of negative taxes designed to subsidize the wages of the working poor - ensured that the income tax plays an important part in the lives Americans from every background.

Many struggling workers today have reason to exclaim "thank God for tax day!" In terms of those it touches, the story of the income tax has been one of relentless expansion. How much any given taxpayer pays has been much more complicated. At the most basic level - the rate of tax set by Congress - the burden of the income tax grows along with how much a taxpayer earns. How they earn income also matters. The results - famously illustrated by Warren Buffet's observation that he pays a lower rate of tax than his secretary - can be counterintuitive.

Despite such quirks, an overarching pattern on rates appears clear. First one World War then another triggered a sharp rise in rates only to be followed by a steady fall. Recent critiques focused on top marginal rates seize on that pattern to highlight the failure of the income tax to curb inequality.

\section{$D$ Rates, loopholes and enforcement}

The Grand Bargain hints at why a focus on rates misses the mark. When the Grand Bargain was struck, growing evasion and avoidance had already made the U.S. income tax surprisingly porous, with "high rates tempered by many avoidance possibilities" (Surrey, 1957, p. 1150). Legislative loopholes had made many affluent taxpayers learn to stop worrying and love the income tax.

Falling rates alone do not explain the Grand Bargain's diminished appeal. The tax breaks that would compel Stanley Surrey to create the tax expenditure budget highlight a very different balance of power between tax authorities and elites at the time the Grand Bargain was struck than those high nominal rates might suggest. Thanks to such tax breaks, in Surrey's day, planning could often deflect the blow of rates above $70 \%$.

But they could not do so without risk. Even half a century ago, tax authorities could neither detect nor defeat every avoidance scheme. Yet enforcement remained a real threat. Top rates have fallen significantly since the Grand Bargain was struck, but an accelerating decline in the ability of tax authorities to challenge aggressive taxpayer behavior matters more. As tax rates fell, the value of the tax benefits the Grand Bargain promised did the same. Even those sharp declines fail to paint an accurate picture of the falling burden the income tax poses for wealthy taxpayers. Tax rates have fallen in half. The drop-off in enforcement has been steeper.

A decade ago, a typical U.S. taxpayer faced an audit risk four times smaller than they would have in the 1960s (Slemrod and Bakija, 2008, p. 181). And since then, that trend has only gained momentum. A systematic effort to reduce funding to the Internal Revenue Service has further hobbled tax enforcement, as highlighted by the 2020 Treasury report titled "High-Income Nonfilers Owing Billions of Dollars Are Not Being Worked by the Internal Revenue Service." If shrugging off the burden of the income tax has become as simple as not filing a return, the tax advantages of the private foundation mean nothing at all.

The Grand Bargain's power can be explained in part by an implicit threat such high tax rates might be enforced. Today, the likelihood of enforcement has fallen even more sharply 
than rates. Lower rates were precisely what Surrey hoped to achieve with his tax expenditure budget, with "all economic income . . . taxed, and the top rate lowered to 35 percent" (Surrey, 1973, p. 226). But he intended "tax-rate reductions for the wealthy" to be paired with "the closing of a number of loopholes which the public cannot understand" (Surrey, 1957, p. 1151).

\section{Entitlement and entitlements}

The Grand Bargain was struck at a moment when high post-World War II rates had yet to fall but had already worn out their welcome. The Grand Bargain did not invent, but did reinvent, the foundation. Surrey once considered foundations symbols of a tax system that stealthily favored insiders. He drily noted, for example, that "[o]n July 30, 1955, Congressman Curtis of Missouri introduced a private bill for the relief of the Cannon Foundation, which had been established by Congressman Cannon of Missouri” (Surrey, 1957, p. 1178).

The Grand Bargain rehabilitated foundations by imposing clear limits on their activities and on the tax benefits of giving. As his tax expenditure budget expanded the tax base by thrusting loopholes into the spotlight, the Grand Bargain steered elites towards philanthropy by forcing them to make an easy choice between the possibility of lurid headlines for tax avoidance and the certainty of flattering coverage for charitable giving. The resulting truce between wealthy taxpayers and the public would help philanthropy flourish in the United States.

Central to the Grand Bargain's success was the myth that it made both sides winners. While taxpayers and the public each yielded on key points, they had little information about the value of the tax breaks at stake. Both the public and elites could believe that the costs of philanthropy were borne by someone else thanks to a virtuous counterpart to Murphy and Nagel's everyday libertarianism. Murphy and Nagel note that by the 1990s, many taxpayers had come to believe themselves entitled to the entirety of their pre-tax holdings and to see any imposition of tax as an affront (Murphy and Nagel, 2002, p. 9). In the 1950s and 1960s, those battle lines had not yet hardened.

Trust comes much more easily when you can believe you have an opportunity to gamble with house money, with nothing to lose and everything to gain. Against a backdrop of high nominal rates and rampant planning, elites and the public could each place very different values on the tax breaks delivered by the Grand Bargain. The Grand Bargain, as Surrey tells it, drove him to put a price tag on the tax law's hidden subsidies, fueling the creation of the tax expenditure budget.

When the Grand Bargain was struck, taxpayers and policymakers lacked even that rudimentary framework to shape their expectations. The tax expenditure budget Surrey popularized fundamentally changed the way policymakers approach tax breaks, highlighting that tax breaks for charitable giving reduce tax revenues by more than $\$ 50$ billion each year. No longer would "tax expenditures tumble into the law without supporting studies, being propelled instead by clichés, debating points, and scraps of data and tables that are passed off as serious evidence" (Surrey, 1973, p. 6).

\section{A Control}

The architecture of the Grand Bargain also allowed each to feel they controlled the disposition of foundation assets. Public control took the form of clear expectations on the timing, transparency and targeting of foundation spending. For their part, philanthropists could rightly claim authorship of foundation achievements as they both exercised day-to-day control and continued 
to manage the capital that fueled their efforts. The Grand Bargain again let both be sides be winners.

Rob Reich describes a long-ago antecedent to the Grand Bargain that helps explain its power. He examines an Athenian "system whereby wealthy citizens could make voluntary contributions to various state projects that were of benefit to the entire citizenry, or demos." Even when vital to its survival, Athens did not quite compel these philanthropic - here liturgical efforts. In Reich's words, "[1]iturgies in democratic Athens became a system of public finance via private contribution, something akin to a system of taxation" (2018, p. 31). Rather than compulsory, the Athenian system made contributions voluntary.

The liminal nature of that system - almost, but not quite, a tax - achieved much the same result as the Grand Bargain. Wealthy Athenians could qualify for a safe harbor - a "temporary exemption" - from that near-tax by, say, voluntarily funding the construction of a trireme warship. Reluctant elites knew they might be enlisted to build and captain such a vessel by selection from the registers of wealthy people kept by the state. But even then, the liturgical system allowed the chosen individual an alternative. By identifying a wealthier citizen - not already exempt - they could shift the burden by invoking the antidosis procedure, which would require whichever citizen a trial determined was wealthier to fund the effort.

That liturgical system relied only indirectly on state power. The wealthiest citizens might recognize the logical inevitability of being called on to make a contribution. Anticipating their selection by the state or a challenge by a less wealthy neighbor, they enjoyed the luxury of transforming an obligation into an act of generosity. Ensuring that civic burdens fell fairly on the backs of the Athenian people while "preserving certain privileges for the wealthy, such as honor, gratitude, and status as a civic benefactor" that liturgical process accomplishes just what Carnegie envisioned (Reich, 2018, p. 34).

The Grand Bargain did much the same. With triremes replaced by private foundations and antidosis by audits, the Grand Bargain allowed wealthy Americans to trade the complexities and risks of tax planning for the simplicity of honor and gratitude. But today, we live in Surrey's world. Any bargains struck will not be paid for with house money.

Just like their liturgical counterparts, for the past half century, philanthropists have been able to trade state compulsion for public gratitude. Both the Grand Bargain and the Athenian liturgical system represented a partnership between the public - the demos - and wealthy elites. Against the backdrop of (nominally) high tax rates, the Grand Bargain achieved what Reich describes as a "balance between plutocratic voice and democratic voice" that did not depend on the government's power over elites $(2018$, p. 140). The mere possibility that their tax planning might unravel in the harsh glare of public scrutiny would have made "honor, gratitude and status as a civic benefactor" every bit as appealing as it once was to wealthy Athenians.

\section{B Optimal rates}

Encouraging future Chans and Zuckerbergs to embrace private foundations could be as straightforward - and every inch as difficult - as recreating the conditions that prevailed in 1969. The income tax presents a particularly tempting opportunity to turn the clock back. Doubling the top marginal income tax rate from $37 \%$ to $74 \%$, for example, should, after all, make tax breaks twice as appealing.

That simple math obscures a more complex reality. Recent interest in sharply higher tax rates can be traced to the work of economists focused on a narrow question. Diamond and Saez worked to identify the "optimal" tax rates for high-income earners. Relying on key assumptions, they concluded that tax rates twice as high as those in effect currently could be imposed 
without distorting behavior over the short run. Diamond and Saez do note that over the long term, high rates could affect choices about education and careers in ways that would be decidedly suboptimal.

Diamond and Saez show that even surprisingly high rates would have little immediate impact on top earners. But they offer an important caveat. If avoidance and evasion remain possible, those high rates would mean little in terms of increased revenues. In order to have an impact, they would need to be paired with "base broadening and tax enforcement" (Diamond and Saez, 2011, p. 173). Simply put, taxpayers must have none of the escape hatches Surrey worried about.

In practice, returning rates to levels not seen for decades may be the easy part. Base broadening might mean, for example, reversing changes that now result in dividends paid to stockholders once taxed at $90 \%$ benefitting from capital gain rates of $20 \%$. Without countless such adjustments, doubling the top marginal rates might not impact the treatment of elites at all.

\section{Philanthropic windfalls}

High tax rates on their own will not produce the trust once supplied by the Grand Bargain and will not generate big tax payments by wealthy individuals. Surrey's tax expenditure budget illustrates why. Since the concepts embodied in the tax expenditure budget were in their infancy and despairing of the prospect of explaining the excessive generosity of the tax treatment of charitable gifts the tax expenditure budget targeted - Surrey offered a stylized example. He underscored how entirely legal tax planning could produce surprising results:

If a person in the 70 percent top bracket informs the Government he is selling fully appreciated stock to pay his tax bill or to obtain cash for other reasons and would like $\$ 100$ paid to a philanthropy, the Government pays the $\$ 100$ to that philanthropy and also pays the person $\$ 5$ - or perhaps $\$ 6.50$ or even $\$ 15.50$.

(Surrey, 1973, p. 227)

His point was simple. Combining the tax benefits granted to contributions of appreciated property - deduction of its full value plus exclusion of all gain from income - can transform a gift into a windfall. Before the Grand Bargain was struck, philanthropy might cost philanthropists less than nothing.

A charitable contribution of appreciated property could be more than fully paid for with the tax breaks it would generate, resulting in a net after-tax payment to - not from - a donor. For the Grand Bargain, that would prove a help rather than a hindrance. When a charitable gift can more than pay for itself while loopholes cause marginal rates above $70 \%$ to loosen their grip, notions of entitlement like those Murphy and Nagel found problematic become meaningless. From the taxpayer's perspective, the pain of curtailed tax preferences and increased accountability trumped even a modest risk of being dragged into court and compelled to pay tax at a $70 \%$ rate. From the public's perspective, curbing abuses to boost tax revenues while asserting firmer control over the operations of foundations would have been equally appealing.

With high rates and robust enforcement, philanthropic tax preferences would, of course, once again become appealing for the wealthy. But not for the demos. Why not just keep the revenues and allow philanthropic entrepreneurs to compete for funding?

The same would be true if current rates were imposed broadly and enforced vigorously. A top tax rate approaching $40 \%$, if wealthy taxpayers actually expected to pay it, could nudge them towards private foundations. High rates, unenforced and under threat by loopholes, would not. 


\section{Interests, not price}

The Grand Bargain's success lay in its ability to elude the question of how heavy a tax burden should fall on elites. Rather than focusing on price (here, tax), elites and the demos had the luxury of focusing on interests. ${ }^{2}$ The Grand Bargain offered both respectability and the modern-day equivalents of triremes. Impossible in the zero-sum world Surrey fought for, the Grand Bargain made winners of both the public and elites.

In the pre-tax expenditure budget era, the Grand Bargain's price remained obscure. While precisely what Surrey lamented, the resulting lack of salience of cost made agreement possible. The private foundation gave the wealthy license to gamble their fortunes on idiosyncratic visions of public benefit. And it allowed the public to believe that elite philanthropy cost them nothing.

An exchange of respectability elites could secure nowhere else for a rescue the public could hope to receive from no one else forged the trust at the heart of this modern-day liturgy. Rekindling that trust through the income tax would be difficult precisely because of the tax expenditure budget. Because of Surrey's great success, price has taken center stage (Sellen, 2021, p. 1).

\section{A Converging political interests}

Fortunately, the Grand Bargain itself suggests another approach. Although its tax aspects loom large, the Grand Bargain did much more than remake the tax treatment of elite philanthropy. Today, political spending presents a tableau of unconstrained power hardly more reassuring than the one Surrey described half a century ago. Surrey's cartographic feat - mapping the terrain of tax breaks - has not been, and perhaps could not be, replicated for political spending. Certainly, no one has yet created political influence budget.

In principle, that absence creates an opening. Rather than attempting to craft an optimal suite of tax incentives - bargaining over price - to cement a new philanthropic partnership between elites and the public, it offers an opportunity to bargain over interests. What minimum standards elites and the public might jointly impose on political spending matters less than the ability to find common ground.

Private foundations could, for example, be allowed to make contributions on the same terms as individuals, effectively "tak[ing] a more general approach that is consistent across both the political entities and charitable organisations performing them" rather than merely attempting "to regulate the definition of charitable purposes and the types of activities that may advance them" (Carmichael, 2021, pp. 1-2). Many philanthropy LLCs make such political contributions. In 2020, the Emerson Collective contributed over a quarter of a million dollars to the Democratic party. Limiting - and clawing back the value of any tax benefits from - any political contributions by foundations, rather than punishing them as current law does, could make foundations more appealing without making them more costly in terms of either direct or tax expenditures.

Just as the Grand Bargain nurtured expectations regarding philanthropic activity, a new compromise could draw clear lines between forms of philanthropic political engagement. By ensuring accountability for those types of political expenditure deemed philanthropically compatible, such an arrangement would reduce the opportunity costs of embracing private foundations without creating new sources of unobserved political influence. Crafted carefully, such minimum standards could benefit both elites and the demos by preserving a balance between plutocratic and democratic voice. 


\section{$B$ Bargaining in the shadow of a wealth tax}

One could also draw a different lesson from the Grand Bargain's success. That both elites and the public could claim victory in the Grand Bargain does not, of course, mean that either was correct. The public may have been hoodwinked into believing that a combination of high nominal and low effective tax rates could constrain elite influence by promoting philanthropy. Wealthy taxpayers arguably agreed to minimum standards and modest tax burdens to ward off what they did not yet recognize as a waning threat of enforcement. Whatever they believed, neither truly gambled with house money.

Today's wealth tax proposals - and the fundamental disagreements that surround them could allow elites and the public to replicate the Grand Bargain's feat. The wealth tax remains nearly as unmapped today as the income tax was before Surrey conquered it. Its advocates, perhaps naively, see an opportunity to realize the unfulfilled promise Jennings Bryan once saw in the income tax, finally "put[ting] the burdens of government justly upon the backs of the people." Its critics see little more than a return of the evasion and avoidance that Surrey decried. Both cannot be true, but since no U.S. wealth tax has ever been enacted, this particular Schrödinger's cat remains both alive and dead.

Today, estimates of the revenues a wealth tax would raise vary by an order of magnitude. The success of the Grand Bargain suggests that there will be no better time to forge an agreement between elites and the demos on the wealth tax's treatment of philanthropy than before we know its measure. Absent a compromise, both sides risk being left with a losing hand.

High effective wealth tax rates would profoundly impact elites. A wealth tax riddled with loopholes and saddled with inadequate enforcement would leave the public with little to show for their efforts. Neither can discount the possibility that the strong version its advocates envision or the weak version its critics fear will materialize. Better, perhaps, to gamble on the impact philanthropy can have on public problems and elite reputations than to risk a toothless or crushing wealth tax.

The public would, of course, prefer a wealth tax able to bring elite influence to heel with high rates, a broad base and robust enforcement. Elites, on the other hand, undoubtedly prefer the freedom the opposite would bring. Given the wide range of possible outcomes, a substantial opportunity to find common ground would exist.

A wealth tax that falls more lightly on assets placed in a private foundation than it does on assets placed in a philanthropy LLC might nudge elites rather burdening them. The results could revive the Grand Bargain, capitalizing on the uncertainty surrounding the wealth tax today to burnish the appeal of private foundations at a time when some of the wealthiest philanthropists have turned to other vehicles. The public might just accept the possibility of substantial lost tax revenues as the price of reimposing minimum standards on elite philanthropy. For their part, elites would eliminate a non-trivial risk that a strong wealth tax would leave them footing the bill for today's triremes, without the benefit of gratitude or honor.

\section{Conclusion}

In some ways, philanthropists and social entrepreneurs could not be more different. But both depend on trust to have access to capital. Social entrepreneurs have been unable to persuade investors to trust them, just as they find themselves unable to trust investors. The results for the growth of social enterprise have been as predictable as they have been disappointing.

Philanthropists hope to retain, rather than gain, access to capital. The Grand Bargain allowed them to do that in exchange for embracing a suite of rules that limited their freedom and 
heightened transparency. Chafing under the burdens of the Grand Bargain, philanthropists have turned to alternatives to the private foundation. Renewed interest in steeply progressive taxes highlights the fragile benefits the Grand Bargain offers to the wealthy and the potential consequences of lost trust. A potent wealth tax would not leave the wealthiest philanthropists entirely without access to capital, but it could represent the end of the fruitful partnership forged by the Grand Bargain a half century ago.

\section{Notes}

1 In 1913, 7 cents would have been collected in tax on the last dollar earned by a prosperous taxpayer. In 2020, after more than a century, that burden would rise more than fivefold to 37 cents. While striking, that contrast actually understates the changes that have marked the income tax's tenure (Roberts, 2014, pp. 932-939).

2 In Getting to Yes, the classic vision of bargaining (over positions such as price) is contrasted against bargaining over interests. Bargaining over interests allows two sides to reach agreement by focusing on aspects of an arrangement that are not zero sum. The authors offer an example of farmers and oil producers realizing that since it would take at least that long to begin drilling, waiting three months to evict farmers after oil was discovered rather than doing so immediately would benefit both the farmers (harvesting crops crucial to their livelihoods) and the oil companies (drilling as soon as possible) (Fisher et al., 2011, pp. 5-6).

\section{References}

Bank, S. (2017) 'When Did Tax Avoidance Become Respectable', Tax Law Review, 71(1), pp. $123-178$.

Brakman Reiser, D. and Dean, S. (2017) Social Enterprise Law: Trust, Public Benefit and Capital Markets. New York: Oxford University Press.

Carmichael C. M. (2022) Charitable ends (perhaps) by political means: what are the governments regulating?, Routledge, pp. 95-114

Carnegie, A. (1889) 'Wealth', The North American Review, 148(391), pp. 653-664.

Diamond, P. and Saez, E. (2011) 'The Case for a Progressive Tax: From Basic Research to Policy Recommendations', Journal of Economic Perspectives, 25(4), pp. 165-190.

Fisher, R., Ury, W. and Patton, B. (2011) Getting to Yes: Negotiating Agreement Without Giving in. New York: Penguin.

Jennings Bryan, W. (1896) 'The Cross of Gold', Speech Delivered before the National Democratic Convention at Chicago, 9 July 1896.

Kohler, S. (2007) 'The Emergency Medical Services Program of the Robert Wood Johnson Foundation', available at https://cspcs.sanford.duke.edu/sites/default/files/descriptive/emergency_medical_services_program.pdf (accessed: 27 January 2021).

Murphy, L. and Nagel, T. (2002) The Myth of Ownership: Taxes and Justice. New York: Oxford. [OECD Policy Brief].

OECD. (2020) 'Taxation and Philanthropy', available at https://doi.org/10.1787/df434a77-en (accessed: 13 September 2021).

Reich, R. (2018) Just Giving: Why Philanthropy Is Failing Democracy and How It Can Do Better. Princeton: Princeton University Press.

Roberts, T. (2014) 'Brackets: A Historical Perspective', Northwestern University Law Review, 108(3), 925-958.

Sellen C. (2022) Philanthropy as a self-taxation mechanism with happy outcomes: crafting a new public disourse, Routledge, pp. 298-324

Slemrod, J. and Bakija, J. (2008) Taxing Ourselves: A Citizen's Guide to the Debate Over Taxes. Cambridge: MIT Press.

Surrey, S. (1957) 'The Congress and the Tax Lobbyist: How Special Tax Provisions Get Enacted', Harvard Law Review, 70(7), 1145-1182.

Surrey, S. (1973) Pathways to Tax Reform: The Concept of Tax Expenditures. Cambridge: Harvard University Press.

Treasury Inspector General for Tax Administration. (2020) 'High-Income Nonfilers Owing Billions of Dollars Are Not Being Worked by the Internal Revenue Service', available at https://www.treasury. gov/tigta/auditreports/2020reports/202030015fr.pdf (accessed: 13 September 2021).

[Zolt (2021) from collected volume]. 